\title{
OPEN Activated Carbons from Hydrochars Prepared in Milk
}

\begin{abstract}
Salwa HajYahia ${ }^{1,2}$, Kian Keat Lee ${ }^{1}$, Brahim Ayed ${ }^{2,3}$, Niklas Hedin $^{1}$ \& Tamara L. Church ${ }^{1 *}$
Hydrothermal carbonization converts organics in aqueous suspension to a mixture of liquid components and carbon-rich solids (hydrochars), which in turn can be processed into activated carbons. We investigated whether milk could be used as a medium for hydrothermal carbonization, and found that hydrochars prepared from milk, with or without an added fibrous biomass, contained more carbon (particularly aliphatic carbon), less oxygen, and more mineral components than those prepared from fibrous biomass in water. Activated carbons produced from hydrochars generated in milk had lower specific surface areas and $\mathrm{CO}_{2}$ capacities than those from hydrochars formed in water; however, these differences disappeared upon normalizing to the combustible mass of the solid. Thus, in the context of $\mathrm{N}_{2}$ and $\mathrm{CO}_{2}$ uptake on activated carbons, the primary effect of using milk rather than water to form the hydrochar precursor was to contribute inorganic mass that adsorbed little $\mathrm{CO}_{2}$. Nevertheless, some of the activated carbons generated from hydrochars formed in milk had specific $\mathrm{CO}_{2}$ uptake capacities in the normal range for activated carbons prepared by activation in $\mathrm{CO}_{2}$ (here, up to $1.6 \mathrm{mmol} \mathrm{g}^{-1} \mathrm{CO}_{2}$ at 15 $\mathrm{kPa}$ and $0^{\circ} \mathrm{C}$ ). Thus, hydrothermal carbonization could be used to convert waste milk to hydrochars and activated carbons.
\end{abstract}

Milk is produced on an enormous scale, and as a result, so is waste milk. In Europe, $13 \%$ of milk produced is wasted, and in North Africa and West and Central Asia, the value is $20 \%{ }^{1}$. In both regions, $3.5 \%$ of the milk produced is wasted at the production phase ${ }^{1}$, where it could potentially be recovered relatively easily. Even in Sweden, where an exceptionally low percentage of milk is wasted at production, the amounts of milk waste generated are large. For example, $0.32 \%$ of milk produced at Swedish farms in 2011 was discarded at the farm, primarily following antibiotic treatment of the cows for mastitis; this amounts to more than 9000 tons of milk ${ }^{2}$. Related to the issue of waste milk is dairy wastewater, which is composed of milk as well as additional water and detergents used for cleaning and sanitizing equipment ${ }^{3}$.

Milk is an aqueous dispersion (in the case of homogenized milk) or suspension (non-homogenized milk) of fats, proteins, and sugars, and also contains inorganic cations including $\mathrm{K}^{+}, \mathrm{Na}^{+}, \mathrm{Ca}^{2+}$, and $\mathrm{Mg}^{2+4}$. Aqueous preparations of organics, including suspensions of biomass, can be converted to carbon-rich solids called hydrochars via hydrothermal carbonization, i.e. by heating to (typically) $180-250^{\circ} \mathrm{C}$ under autogeneous pressure ${ }^{5-10}$. The ability to convert wet biomass is the main process-related advantage of hydrothermal over pyrolytic carbonization ${ }^{7}$. Yoghurt (10 wt\% in water) has been converted to a hydrochar that was evaluated as fuel ${ }^{11}$. Additionally, the hydrothermal carbonization of milk has been used as the first step in the synthesis of antibacterial carbon dot-Ag nanoparticle composites ${ }^{12}$.

Hydrochars from biomass can be activated to give activated carbons $s^{5,8,9,13-15}$. Biomass types that have been converted to activated carbons using this method include many lignocellulosic waste products ${ }^{16,17}$, for example bark $^{14}$, sawdust ${ }^{15}$, rye straw ${ }^{18}$, grasses ${ }^{19,20}$, horse manure ${ }^{19}$, beer waste ${ }^{19}$, japonica ${ }^{20}$, and sewage sludge $e^{21}$. However, hydrochars have also been prepared from biomass sources with higher fat content, in particular microalgae $\mathrm{e}^{22}$, and subsequently processed into activated carbons. Activated carbons, including those derived from hydrochars, can be used as $\mathrm{CO}_{2}$ sorbents ${ }^{7,23-25}$, and small amounts of $\mathrm{Ca}^{2+}$ increased the $\mathrm{CO}_{2}$-uptake capacity of polymer-derived activated carbons ${ }^{26}$.

To evaluate hydrothermal carbonization as a method of using waste milk, we converted homogenized milk to hydrochars that were characterized and activated to give activated carbons (Fig. 1) whose properties and $\mathrm{CO}_{2}$ sorption abilities were measured. Milk was also studied as a medium for the hydrothermal carbonization of fibrous biomass; thus, corn husk or flax fiber (corn husk is a waste product, and flax fibers are relevant to Swedish

${ }^{1}$ Materials and Environmental Chemistry, Stockholm University, Svante Arrhenius väg 16C, Stockholm, SE-106 91, Sweden. ${ }^{2}$ Department of Chemical Engineering Process, National Engineering School of Gabes, University of Gabes, Gabès, Tunisia. ${ }^{3}$ Laboratory of Materials, Crystal Chemistry and Applied Thermodynamics, Faculty of Science of Monastir, Monastir, Tunisia. *email: tamara.church@mmk.su.se 


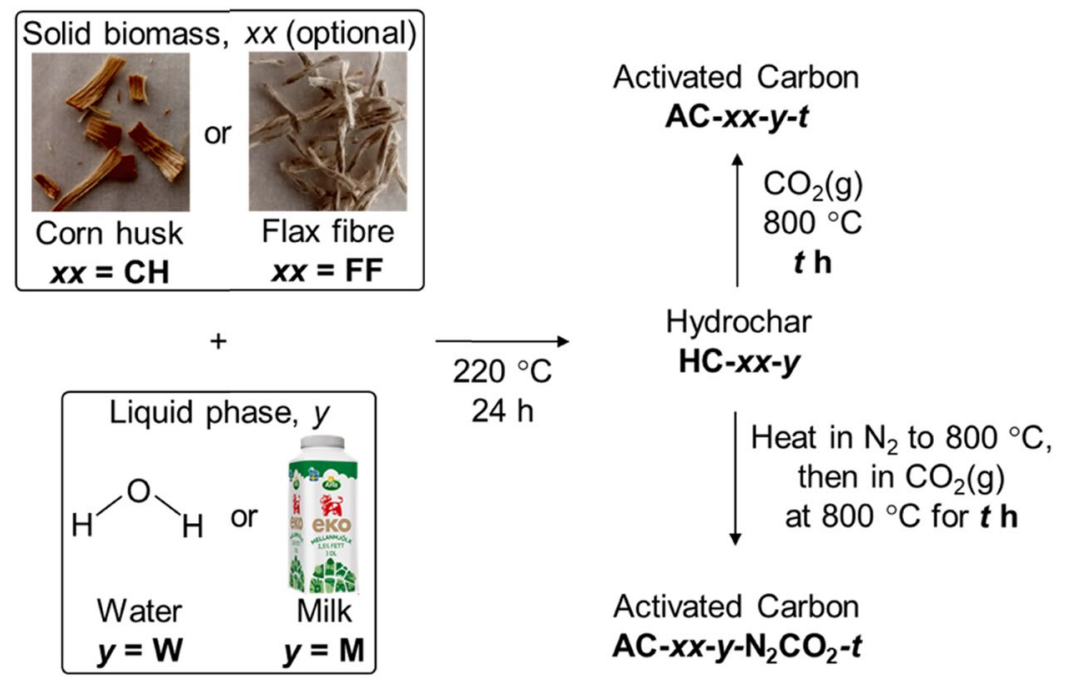

Figure 1. Summary of the synthesis of hydrochars (HCs) and activated carbons (ACs) described in this work, as well as the sample naming system (shown in bold characters).

agriculture) were converted to hydrochars in water and in milk, and then activated to give activated carbons whose properties were compared.

\section{Experimental Section}

The syntheses of hydrochars and activated carbons are described here; complete experimental and analytical details are given in the Supplementary Information.

Hydrothermal carbonization. Flax fibers (unbleached, Växbo Lin, Sweden) and corn husks (removed from corn obtained from a local market) were divided into $1-\mathrm{cm}$ pieces and allowed to dry at room temperature for $3 \mathrm{~d}$ to reach constant mass before hydrothermal carbonization. In each hydrothermal carbonization, a Teflon vessel was charged with liquid ( 80 or $200 \mathrm{~mL}$ of deionized water or milk), and solid biomass ( $0.1 \mathrm{~g}$ flax fiber or corn husks per $\mathrm{mL}$ water or milk) was added when desired. The vessel was sealed in an autoclave reactor, which was transferred to a Thermo Scientific Heraeus oven and heated at $200^{\circ} \mathrm{C} \mathrm{h}^{-1}$ to $220^{\circ} \mathrm{C}$, held at that temperature for $24 \mathrm{~h}$, and then allowed to cool to room temperature at $80^{\circ} \mathrm{C} \mathrm{h}^{-1}$. The resulting solid was recovered by filtration, washed several times with deionized water, and dried at $100^{\circ} \mathrm{C}$ for $24 \mathrm{~h}$ before it was crushed and sieved to give particles with $\mathrm{d}<1 \mathrm{~mm}$. This solid is labeled HC- $x x-y$, where $x x=\mathrm{CH}$ or FF for samples produced from corn husk or flax fiber, and $y=\mathrm{W}$ or $\mathrm{M}$ for samples produced in deionized water or milk. The hydrochar produced from milk without added solid is labeled HC-M.

Activation. HC- $x x-y(1-3 \mathrm{~g})$ was charged into a vertical fixed-bed reactor and heated at $600{ }^{\circ} \mathrm{C} \mathrm{h}^{-1} \mathrm{under}$ $98 \mathrm{~L} \mathrm{~h}^{-1}$ gas $\left(\mathrm{CO}_{2}\right.$ or $\left.\mathrm{N}_{2}\right)$ to $800^{\circ} \mathrm{C}$. The reactor was then held under $98 \mathrm{~L} \mathrm{~h}^{-1} \mathrm{CO}_{2}$ flow for $4-20 \mathrm{~h}$ before it was allowed to cool to room temperature. The solid was removed from the reactor, crushed, and sieved to particles with $\mathrm{d}<1 \mathrm{~mm}$. The resulting samples that were both heated to and held at $800{ }^{\circ} \mathrm{C}$ under $\mathrm{CO}_{2}$ are labeled AC- $x x-y$ - $t$, where $x x$ and $y$ give the details of hydrothermal carbonization (see above) and $t$ gives the activation time in $\mathrm{h}$. Samples that were heated to $800^{\circ} \mathrm{C}$ under $\mathrm{N}_{2}$ and then held at that temperature under $\mathrm{CO}_{2}$ are labeled $\mathrm{AC}-x x-y-\mathrm{N}_{2} \mathrm{CO}_{2}-t$.

\section{Results and Discussion}

Hydrochars. The hydrothermal carbonization of flax fiber and corn husk in water at $220^{\circ} \mathrm{C}$ for $24 \mathrm{~h}$ gave hydrochars in 40 and 34\% yield, in line with yields obtained in other studies of hydrothermal carbonization at moderate temperature and extended times ${ }^{6}$. More hydrochar was obtained when homogenized milk was used as the liquid for hydrothermal carbonization. The solid yields from hydrothermal carbonization in milk can be estimated by taking the combined mass of added solid plus solid components in the milk as the solid input; using this method, the yields from the hydrothermal carbonization of flax fiber and corn husk in milk were $81 \%$ and $70 \%$.

The hydrochars produced in milk contained more $\mathrm{H}$ and $\mathrm{N}$, but less $\mathrm{O}$, than their counterparts produced in water (Table 1). The greater H content was reflected in the IR spectra of the HC- $x x$-M (Supplementary Fig. S1a), which showed much more intense $\nu(\mathrm{C}-\mathrm{H})$ bands, primarily associated with aliphatic $\mathrm{C}-\mathrm{H}$ bonds $\left(3000-2800 \mathrm{~cm}^{-1}\right)$, than the spectra of the HC- $x x$-W. The ${ }^{13} \mathrm{C}$ NMR spectrum of HC-CH-W (Fig. 2a) resembled that reported for HC produced from rye straw at $240{ }^{\circ} \mathrm{C}^{27}$, showing peaks for both saturated $(\delta<80 \mathrm{ppm})$ and unsaturated $(\delta>100 \mathrm{ppm})$ carbons, as well as unsaturated oxygenated groups such as carboxylic acids $(\delta$ $\sim 175 \mathrm{ppm})$ and ketones $(\delta \sim 205 \mathrm{ppm})$. A very small peak at $\delta \sim 72 \mathrm{ppm}$ may have indicated the presence of unreacted sugars or cellulose ${ }^{27,28}$. Extraction of $\mathrm{HC}-\mathrm{CH}-\mathrm{W}$ in acetone lowered the ${ }^{13} \mathrm{C}$ NMR intensity associated with saturated carbons, in particular for the peak at $\delta \sim 30 \mathrm{ppm}$, and the concomitant loss of carboxylic acid and ketone carbons suggested that levulinic acid was a component of the extractable material, which was obtained 


\begin{tabular}{|l|l|l|l|l|l|l|l|l|}
\hline \multirow{2}{*}{ HC- $\boldsymbol{x}$ - $\boldsymbol{y}$} & \multicolumn{3}{|l|}{$\begin{array}{l}\text { Elemental composition } \\
{[\% \text { by mass] }}\end{array}$} & \multicolumn{2}{l|}{$\begin{array}{l}\text { Molar ratio } \\
{[-]}\end{array}$} & $\boldsymbol{S}_{\text {BET }}{ }^{\boldsymbol{b}}$ & Res. mass $^{\boldsymbol{c}}$ \\
\hline $\boldsymbol{x} \boldsymbol{x}$ & $\boldsymbol{y}$ & $\mathbf{m}_{\mathrm{C}}$ & $\mathbf{m}_{\mathrm{H}}$ & $\mathbf{m}_{\mathrm{N}}$ & $\mathbf{n}_{\mathrm{H}} / \mathbf{n}_{\mathrm{C}}$ & $\mathbf{n}_{\mathrm{O}} / \mathbf{n}_{\mathrm{C}}$ & {$\left[\mathbf{m}^{2} \mathbf{g}^{-1}\right]$} & {$[\%]$} \\
\hline \multirow{2}{*}{$\mathrm{CH}$} & $\mathrm{W}$ & 71.0 & 4.73 & 1.71 & 0.79 & 0.23 & 18 & 0.54 \\
\cline { 2 - 10 } & $\mathrm{M}$ & 69.8 & 6.10 & 4.99 & 1.0 & 0.16 & 4.3 & 4.0 \\
\hline- & $\mathrm{M}$ & 62.8 & 6.97 & 5.91 & 1.3 & 0.20 & 4.5 & 7.3 \\
\hline \multirow{2}{*}{$\mathrm{FF}$} & $\mathrm{W}$ & 66.1 & 4.85 & 0.37 & 0.87 & 0.32 & 28 & 0.09 \\
\cline { 2 - 9 } & $\mathrm{M}$ & 73.0 & 6.33 & 4.46 & 1.0 & 0.13 & 5.4 & 3.2 \\
\hline
\end{tabular}

Table 1. Properties of hydrochars (HC) generated from hydrothermal carbonization in water or milk. ${ }^{\mathrm{a}} \mathrm{n}_{\mathrm{O}}$ is approximated as $\mathrm{n}_{\mathrm{O}}=\left[100-\right.$ mass \% remaining after combustion to $\left.800^{\circ} \mathrm{C}-\left(\mathrm{m}_{\mathrm{C}}+\mathrm{m}_{\mathrm{H}}+\mathrm{m}_{\mathrm{N}}\right)\right] / 16$. ${ }^{\mathrm{b}} S_{\mathrm{BET}}=$ Brunauer-Emmett-Teller surface area, calculated over $\mathrm{P} / \mathrm{P}_{0}=0.05-0.25$. ${ }^{\mathrm{c}}$ Res. mass $=$ mass $\%$ remaining after combustion to $800^{\circ} \mathrm{C}$.

(a)

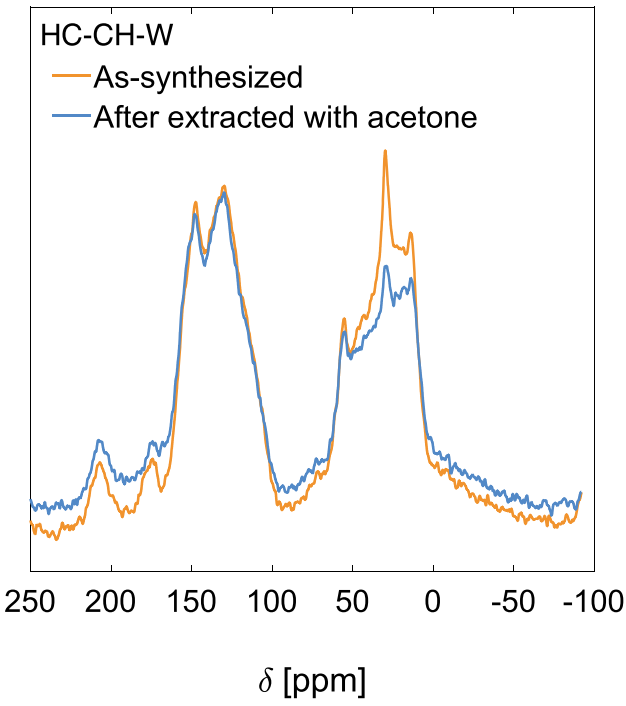

(b)

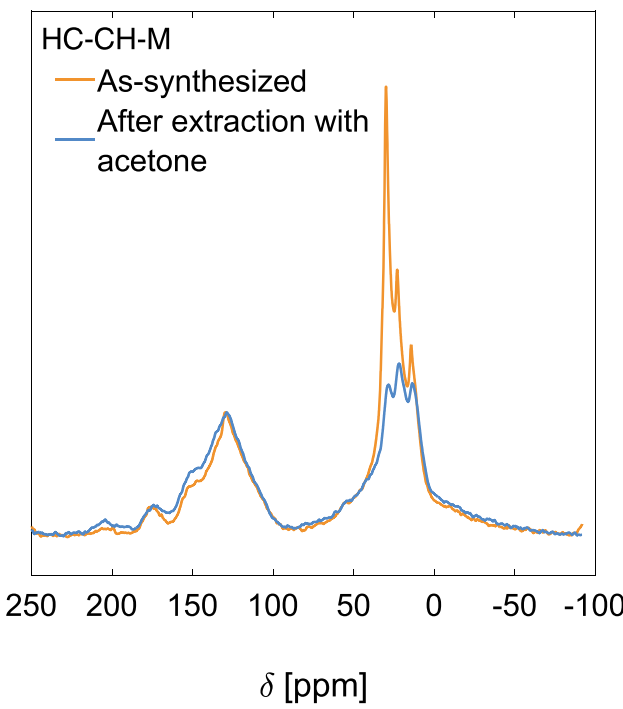

Figure 2. Solid-state $\left\{{ }^{1} \mathrm{H}\right\}{ }^{13} \mathrm{C}$ NMR crosspolarization spectra of hydrochars (HC) produced in water or milk, as-synthesized and following extraction in refluxing acetone for $24 \mathrm{~h}$. (a) HC-CH-W, and (b) HC-CH-M. Magic angle spinning at $14 \mathrm{kHz}$ was used.

as a darkly colored solid. Free levulinic acid has been detected in hydrochars from glucose ${ }^{29}$. In agreement with the IR results, the ${ }^{13} \mathrm{C}$ NMR spectrum of HC-CH-M (Fig. 2b) revealed it to contain a much larger fraction of saturated carbons than HC-CH-W. Further, the fraction of the carbons that were oxygenated $(\delta \sim 150$ and $\sim 50$ $\mathrm{ppm}$ for unsaturated and saturated carbons) was lower in the hydrochar produced in milk, consistent with the lower $\mathrm{n}_{\mathrm{O}} / \mathrm{n}_{\mathrm{C}}$ ratio observed for the hydrochars generated in milk (Table 1$)^{29}$. After extraction with acetone, the fraction of saturated carbons in HC-CH-M fell, and the extract itself was a dark viscous oil. Fatty acids are not readily converted to hydrochar, but do adsorb onto hydrochars formed from sugars $\mathrm{s}^{30}$; they can then be extracted using ethers ${ }^{30,31}$ or ethanol ${ }^{32}$. Therefore, the extractable saturated carbons on HC-CH-M were likely largely from fatty acids. The HC- $x x-\mathrm{M}$ had lower surface areas than the HC- $x x-\mathrm{W}$ (Table 1), and this difference is attributed to extractable molecules adsorbed on and in the pores of the HC- $x x-\mathrm{M}$.

The HC- $x x-\mathrm{W}$ were more thermally stable at lower temperature, losing less than $5 \%$ of their mass when heated in air over $100-250^{\circ} \mathrm{C}$, whereas the HC- $x x-\mathrm{M}$ lost $15-20 \%$ of their mass in the same temperature range (Supplementary Fig. S1b). Heating $\mathrm{HC}-x x$-W to $800^{\circ} \mathrm{C}$ in air left very little residue $(<0.6 \mathrm{wt} \%)$, whereas the hydrochars produced in milk retained 3-8\% of their mass (Table 1), indicating that some of the mineral elements from the milk were retained. The IR spectra (Supplementary Fig. S1a) of the hydrochars produced in milk showed two peaks, at approximately 600 and $560 \mathrm{~cm}^{-1}$, that were not observed for the hydrochars produced in water. The positions and relative intensity of these peaks are consistent with those for vibrations associated with the phosphate groups of apatite ${ }^{33}$, and they may therefore be related to an inorganic phosphate.

Activated carbons. The as-synthesized hydrochars were heated at $800^{\circ} \mathrm{C}$ in $\mathrm{CO}_{2}$ for $4-20 \mathrm{~h}$ to give activated carbons. Very high capacities for $\mathrm{CO}_{2}$ sorption have been observed for hydrochars after activation with $\mathrm{KOH}^{15}$ or $\mathrm{K}_{2} \mathrm{CO}_{3}{ }^{13}$; however, the use of solid etchants requires an additional washing step in the material preparation, and $\mathrm{KOH}$ in particular is corrosive ${ }^{34}$, and we therefore focused on activation with $\mathrm{CO}_{2}$. Generally, hydrochars were heated in $\mathrm{CO}_{2}$ and then held at $800^{\circ} \mathrm{C}$ under $\mathrm{CO}_{2}$, but a modified procedure was also tested for a few samples. Here, the solid was heated to $800^{\circ} \mathrm{C}$ under $\mathrm{N}_{2}$ before the gas stream was changed to $\mathrm{CO}_{2}$ and the sample held at $800^{\circ} \mathrm{C}$ for $20 \mathrm{~h}$. The resulting activated carbons are distinguished with the term ' $\mathrm{N}_{2} \mathrm{CO}_{2}$ ' in the sample name. 

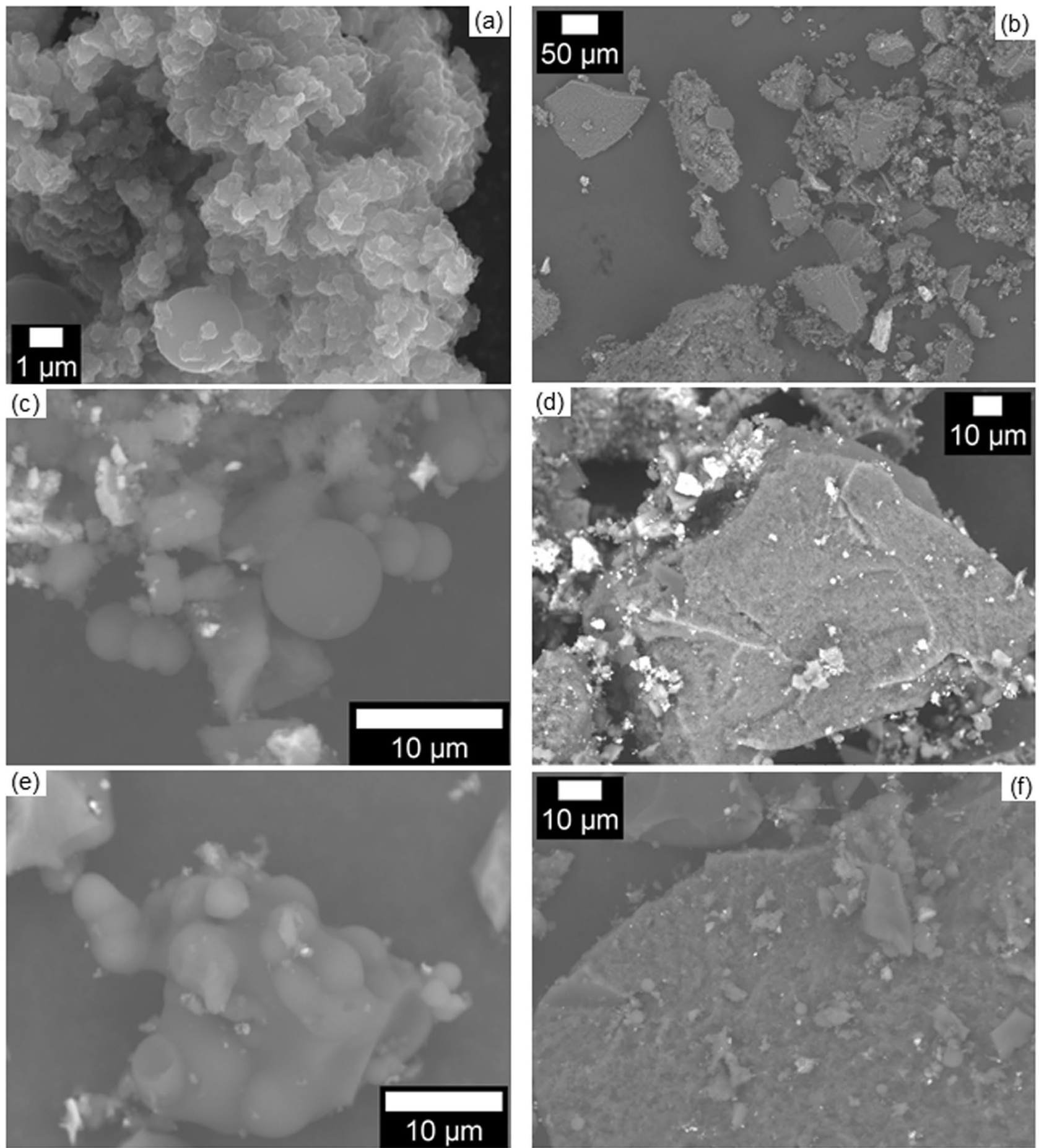

Figure 3. Scanning electron microscope images of activated carbons (ACs) generated from a hydrochar formed in milk without solid precursors. For each sample, a smaller particle is shown on the left, and a larger one on the right. (a,b) AC-M-4; (c,d) AC-M-10; (e,f) AC-M-N $\mathrm{CO}_{2}-20$.

Scanning electron microscope images of activated carbons derived from the HC-M sample produced with no solid biomass (Fig. 3) showed two types of particles. The smaller particles $(\sim 5-50 \mu \mathrm{m}$; Fig. 3a,c,e) seemed smooth and were agglomerations of spheres that were reminiscent of the carbonaceous spheres seen in the hydrothermal carbonization of carbohydrates ${ }^{27,35-38}$, along with more irregular macroporous particles. Energy dispersive X-ray spectroscopy (EDS) of one such particle (Supplementary Fig. S2a) in AC-M-4 indicated that it was composed primarily of carbon and oxygen, but also contained small amounts of calcium, phosphorus, potassium, and magnesium. Larger (hundreds of $\mu \mathrm{m}$ ), irregularly shaped particles with defined edges, sometimes bearing small spheres on their surfaces, were also present (Fig. 3b,d,f), and EDS showed one such particle to be composed of iron and 


\begin{tabular}{|c|c|c|c|c|c|c|c|c|c|c|c|c|}
\hline \multicolumn{3}{|c|}{ AC- $x x-y-t$} & \multicolumn{10}{|c|}{ Activated carbon (AC) } \\
\hline \multirow[b]{2}{*}{$x x$} & \multirow[b]{2}{*}{$y$} & \multirow[b]{2}{*}{$t$} & \multirow[b]{2}{*}{ Yield [\%] } & \multicolumn{3}{|c|}{$\begin{array}{l}\text { Elemental composition } \\
\text { [\% by mass] }\end{array}$} & \multirow[b]{2}{*}{$\mathbf{n}_{\mathrm{H}} / \mathbf{n}_{\mathrm{C}}[-]$} & \multirow[b]{2}{*}{$\begin{array}{l}\text { Non-combustible } \\
\text { mass }^{a}[\%]\end{array}$} & \multirow[b]{2}{*}{$\begin{array}{l}S_{\mathrm{BET}}^{\mathrm{b}} \\
{\left[\mathbf{m}^{2} \mathbf{g}^{-1}\right]}\end{array}$} & \multirow[b]{2}{*}{$\begin{array}{l}\mathrm{V}_{\mu-\text { pore }}{ }^{\mathrm{c}} \\
{\left[\mathrm{cm}^{3} \mathbf{g}^{-1}\right]}\end{array}$} & \multicolumn{2}{|c|}{$\begin{array}{l}\mathrm{CO}_{2} \text { Uptake }\left[\mathrm{mmol} \mathrm{g}^{-1}\right]^{\mathrm{d}} \\
\text { at } 0^{\circ} \mathrm{C} \text { and } P_{\mathrm{CO}_{2}}=\end{array}$} \\
\hline & & & & C & $\mathbf{H}$ & $\mathbf{N}$ & & & & & $15 \mathrm{kPa}$ & $\begin{array}{l}101 \\
\text { kPa }\end{array}$ \\
\hline \multirow{7}{*}{$\mathrm{CH}$} & \multirow{4}{*}{ W } & 4 & 39 & 85.8 & 1.36 & 1.63 & 0.19 & 4.2 & 426 & 0.171 & 1.6 & 3.0 \\
\hline & & 10 & 50 & \begin{tabular}{|l|}
88.8 \\
\end{tabular} & 1.35 & 1.72 & 0.18 & 6.2 & 413 & 0.186 & 1.6 & 3.1 \\
\hline & & 20 & 42 & 73.3 & 0.94 & 1.39 & 0.15 & 12 & 643 & 0.258 & 1.6 & 3.7 \\
\hline & & $\mathrm{N}_{2} \mathrm{CO}_{2}-20$ & 41 & 75.3 & 1.20 & 1.49 & 0.19 & 11 & 748 & 0.299 & 1.7 & 3.9 \\
\hline & \multirow{3}{*}{ M } & 4 & 25 & 61.3 & 0.99 & 4.76 & 0.19 & 25 & 298 & 0.119 & 1.3 & 2.4 \\
\hline & & 10 & 26 & 65.0 & 1.26 & 3.88 & 0.23 & 30 & 457 & 0.181 & 1.6 & 3.1 \\
\hline & & $\mathrm{N}_{2} \mathrm{CO}_{2}-20$ & 41 & 35.4 & 1.03 & 2.19 & 0.35 & 48 & 478 & 0.191 & 0.87 & 2.2 \\
\hline \multirow{3}{*}{$--^{e}$} & \multirow{3}{*}{ M } & 4 & 16 & 43.6 & 1.16 & 3.51 & 0.32 & 28 & 260 & 0.103 & 1.0 & 2.0 \\
\hline & & 10 & 18 & \begin{tabular}{|l|}
47.1 \\
\end{tabular} & 1.18 & 3.61 & 0.30 & 42 & 354 & 0.141 & 1.0 & 2.2 \\
\hline & & $\mathrm{N}_{2} \mathrm{CO}_{2}-20$ & 18 & 53.4 & 1.03 & 4.41 & 0.23 & 28 & 446 & 0.179 & 1.1 & 2.5 \\
\hline \multirow{7}{*}{$\mathrm{FF}$} & \multirow{4}{*}{ W } & 4 & 44 & 93.3 & 1.17 & $<0.10$ & 0.15 & 1.5 & 502 & 0.200 & 1.7 & 3.4 \\
\hline & & 10 & 42 & \begin{tabular}{|l|}
91.7 \\
\end{tabular} & 1.28 & $<0.10$ & 0.17 & 2.7 & 584 & 0.231 & 1.8 & 3.8 \\
\hline & & 20 & 40 & 89.4 & 1.18 & $<0.10$ & 0.16 & 1.5 & 649 & 0.256 & 1.8 & 4.2 \\
\hline & & $\mathrm{N}_{2} \mathrm{CO}_{2}-20$ & 21 & 76.9 & 1.12 & $<0.10$ & 0.17 & 1.2 & 527 & 0.209 & 1.8 & 3.6 \\
\hline & \multirow{3}{*}{ M } & 4 & 40 & \begin{tabular}{|l|}
74.4 \\
\end{tabular} & 1.23 & 3.91 & 0.20 & 12 & 376 & 0.149 & 1.5 & 2.7 \\
\hline & & 10 & 37 & 71.2 & 1.29 & 3.87 & 0.22 & 16 & 414 & 0.164 & 1.6 & 3.1 \\
\hline & & $\mathrm{N}_{2} \mathrm{CO}_{2}-20$ & 21 & 50.0 & 1.09 & 2.39 & 0.26 & 44 & 398 & 0.159 & 0.94 & 2.2 \\
\hline
\end{tabular}

Table 2. Properties of the activated carbons prepared from the activation of hydrochars generated in water

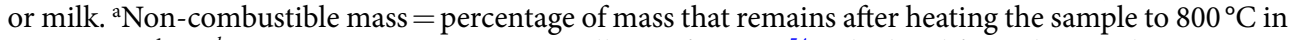
$25 \mathrm{~mL} \mathrm{~min}^{-1}$ air. ${ }^{b} S_{\mathrm{BET}}=$ Brunauer-Emmett-Teller surface area ${ }^{54}$, calculated from the $\mathrm{N}_{2}$ adsorption isotherms (Supplementary Fig. S7) over $\mathrm{P} / \mathrm{P}_{0}=0.01-0.1{ }^{c} \mathrm{~V}_{\mu \text {-pore }}=$ micropore volume, calculated from the $\mathrm{N}_{2}$ adsorption isotherms (Supplementary Fig. S7) using the Dubinin-Radushkevich equation ${ }^{55,56}$ fitted over $\mathrm{P} / \mathrm{P}_{0}=0.0001-$ $0.05 .{ }^{d} \mathrm{CO}_{2}$ uptake at $101 \mathrm{kPa}$ is measured (isotherms in Supplementary Figs S9-S13); $\mathrm{CO}_{2}$ uptake at $15 \mathrm{kPa}$ is interpolated from a two-site Langmuir fit to the isotherm data (details in Supplementary Information section S1.4). ${ }^{e}$ No solid biomass source was added.

oxygen, and to a lesser extent carbon (Supplementary Fig. S2b). We have previously observed Fe in activated carbons generated from hydrochars, even when no Fe precursor was added; this is derived from the stainless steel reactor used during the activation ${ }^{39}$.

The surface morphologies of flax fiber and corn husk (Supplementary Fig. S3a,b) were retained throughout hydrothermal carbonization and activation, with AC-FF-W-10 (Supplementary Fig. S3c) appearing as short fibers, and AC-CH-W-10 (Supplementary Fig. S3d) as broader sheets. These structures were also retained when milk was used in the hydrothermal carbonization (Supplementary Fig. S3e,f), but in that case were accompanied by the carbonaceous spheres and amorphous material seen in the activated carbons produced without solid biomass (Fig. 3).

Activation increased the aromaticity of the carbonaceous solids, as $\mathrm{n}_{\mathrm{H}} / \mathrm{n}_{\mathrm{C}}$ fell in all cases (from $0.79-1.3$ for hydrochars to $0.15-0.34$ for activated carbons; cf. Tables 1 and 2). The formation of partially graphitized carbon was evinced by broad X-ray diffraction (XRD; Fig. 4 and Supplementary Fig. S4) peaks centered at $2 \theta=23-25$ and $43^{\circ}$, which correspond to the (002) and (10) planes of turbostratic carbon ${ }^{40}$, for most samples. These peaks were very weak for samples derived from milk without an additional biomass source (i.e. AC-M- $t$, Supplementary Fig. S4e), and for samples heated to $800^{\circ} \mathrm{C}$ in $\mathrm{N}_{2}$ (Fig. 4, cf. Supplementary Fig. S4). In two samples that were examined with X-ray photoelectron spectroscopy (XPS of AC-CH- $y-\mathrm{N}_{2} \mathrm{CO}_{2}-20$ for $y=\mathrm{W}$ and M; see Supplementary Figs S5 and S6), the C 1s peaks included long slopes toward high binding energies, which supported the presence of graphitic or carbon black-type structures, though detailed deconvolution was not possible.

Whereas activation increased the carbon content of hydrochars formed in water (from $66-71 \mathrm{wt} \% \mathrm{C}$ for HC- $x x-\mathrm{W}$ to $73-94 \mathrm{wt} \% \mathrm{C}$ for AC- $x x-\mathrm{W}-t$; cf. Tables 1 and 2), it decreased carbon content for most of the HC formed in milk (from $62-73 \mathrm{wt} \% \mathrm{C}$ for HC- $x x$-M and HC-M to 35-75 wt\% C for AC- $x x-\mathrm{M}-t$ and AC-M- $t$ ), because the removal (gasification) of organic material during activation caused the mineral components from the milk to make up a larger fraction of the activated carbons. Thus, although the residual mass of the AC- $x x$-W- $t$ samples after combustion to $800^{\circ} \mathrm{C}$ was never greater than $12 \%$, it ranged from $11-48 \%$ for the AC- $x x-\mathrm{M}-t$ samples, with high values being observed particularly for samples with long activation times (Table 2).

There are likely multiple reasons for the larger mineral content of the activated carbons produced from milk-derived hydrochars as compared with activated carbons prepared from hydrochars generated in water. First, there were minerals in the milk, and hence more mineral components were observed in the hydrochars prepared from milk than from water, as expected (see above). Further, the yield from activation of an HC- $x x-\mathrm{W}$ was generally higher than that from activation of HC- $x x$-M when the solid feedstock and activation conditions were the same (Table 2); that is, more mass was removed from $\mathrm{HC}-x x$-M. Thus, either the HC- $x x-\mathrm{M}$ were more readily etched than the HC- $x x-\mathrm{W}$, or the mineral components from milk catalyzed the decomposition of the hydrochars, or both. We cannot reject the former hypothesis, as HC- $x x-\mathrm{W}$ and HC- $x x-\mathrm{M}$ were chemically different (Table 1, 


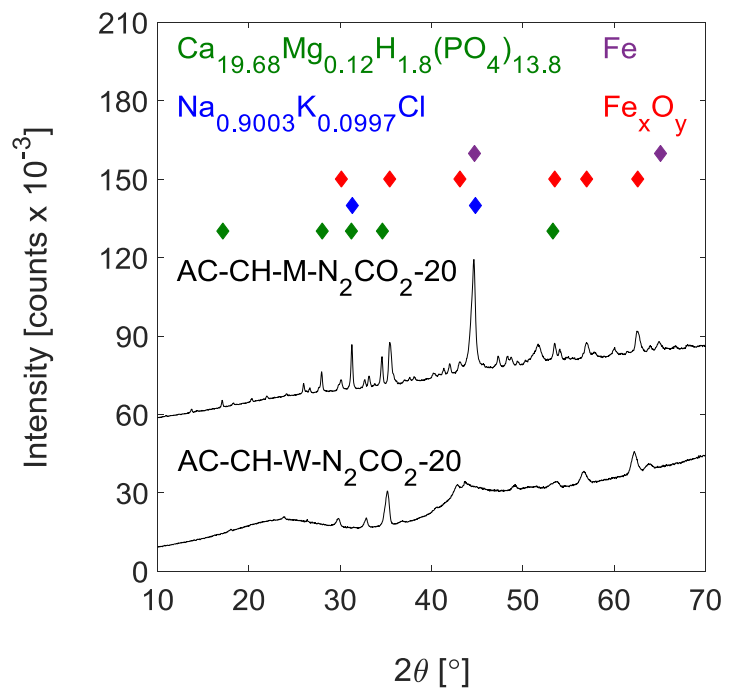

Figure 4. Powder X-ray diffraction patterns of selected activated carbons (ACs). Corn husk (CH) and liquid (water (W) or milk (M)) were heated in a sealed autoclave at $220^{\circ} \mathrm{C}$ to form a hydrothermal carbon that was heated under $\mathrm{N}_{2}$ to $800^{\circ} \mathrm{C}$, then held at that temperature under $\mathrm{CO}_{2}$ for $20 \mathrm{~h}$. Symbols above show the positions of the most intense peaks for relevant inorganic phases. The pattern for $\mathrm{AC}-\mathrm{CH}-\mathrm{M}-\mathrm{N}_{2} \mathrm{CO}_{2}-20$ has been vertically offset for clarity. Diffraction patterns for all ACs are shown in Supplementary Fig. S4.

Fig. 2 and Supplementary Fig. S1); however, the metal ions present in milk likely also affected the process. $\mathrm{Ca}^{2+}$ catalyzes the gasification of biochars in $\mathrm{CO}_{2}{ }^{41}$, and $\mathrm{K}^{+}$salts including $\mathrm{KOH}^{15,35,42,43}, \mathrm{~K}_{2} \mathrm{CO}_{3}{ }^{13,44}, \mathrm{KHCO}_{3}{ }^{45,46}$, and $\mathrm{K}_{2} \mathrm{C}_{2} \mathrm{O}_{4}{ }^{47}$ are used to activate hydrochars and form activated carbons. $\mathrm{Na}^{+}$salts can also be used in the preparation of activated carbons from hydrochars ${ }^{9}$. Elemental analysis of AC-FF-W-10 revealed no detectable $\mathrm{K}$ and only $0.03 \mathrm{wt} \% \mathrm{Ca}$; whereas AC-CH-M-10 contained $0.34 \mathrm{wt} \% \mathrm{~K}$ and $2.7 \mathrm{wt} \% \mathrm{Ca}$. Similarly, XPS (Supplementary Table S1) showed that AC-CH-M-N $\mathrm{CO}_{2}-20$ contained $\mathrm{K}$ and $\mathrm{Ca}$, whereas $\mathrm{AC}-\mathrm{CH}-\mathrm{W}-\mathrm{N}_{2} \mathrm{CO}_{2}-20$ did not. Thus, the $\mathrm{Ca}^{2+}$ and $\mathrm{K}^{+}$in milk were at least partially retained throughout hydrothermal carbonization and activation, and likely contributed to pore development in the activated carbons produced from HC- $x x-\mathrm{M}$ and HC-M.

The primary crystalline calcium-containing phases (Fig. 4 and Supplementary Fig. S4) in the activated carbons prepared from HC- $x x$-M were calcium phosphate (ICSD 00-003-0713) or calcium-rich mixed calcium magnesium phosphates, such as $\mathrm{Ca}_{19.68} \mathrm{Mg}_{0.12} \mathrm{H}_{1.8}\left(\mathrm{PO}_{4}\right)_{13.8}$ (ICSD 01-079-2186) and $\mathrm{Ca}_{19} \mathrm{Mg}_{2}\left(\mathrm{PO}_{4}\right)_{14}$ (ICSD 01-082-9075). The latter two are difficult to distinguish by powder XRD; however, XPS of AC-CH-M-N $\mathrm{CO}_{2}-20$ (Supplementary Table S1) showed no $\mathrm{Mg}$, so the more Mg-rich $\mathrm{Ca}_{19} \mathrm{Mg}_{2}\left(\mathrm{PO}_{4}\right)_{14}$ is less likely to be important. Some potassium may have been present as $\mathrm{K}_{\mathrm{n}} \mathrm{Na}_{1-\mathrm{n}} \mathrm{Cl}(\mathrm{n}=0.2$, ICSD 01-076-3440; $\mathrm{n}=0.0997$, ICSD 01-0750305), but the small amounts involved and the presence of other phases render this assignment uncertain. Neither the calcium (magnesium) phosphates nor $\mathrm{K}_{\mathrm{n}} \mathrm{Na}_{1-\mathrm{n}} \mathrm{Cl}$ were significant in the activated carbons prepared from HC- $x x-$ W. Two significant non-carbon phases were observed for activated carbons derived from hydrochars formed in both water and in milk; these were $\alpha$-Fe (ISCD 01-071-4648), which gave rise to sharp peaks at $2 \theta=44$ and $65^{\circ}$, and an iron oxide (cubic $\mathrm{Fe}_{3} \mathrm{O}_{4}$, inverse spinel $\mathrm{Fe}_{3} \mathrm{O}_{4}$, or $\gamma-\mathrm{Fe}_{2} \mathrm{O}_{3}$; these produce similar powder XRD patterns), consistent with the observation of an iron oxide by EDS (Supplementary Fig. S2). Nevertheless, based on XPS the total Fe in the activated carbons was small (Supplementary Table S1).

A consequence of the high inorganic content of the AC- $x x$-M- $t$ was that they displayed lower apparent specific surface areas $S_{\mathrm{BET}}\left(300-480 \mathrm{~m}^{2} / \mathrm{g}\right)$ than the AC- $x x-\mathrm{W}-t\left(400-750 \mathrm{~m}^{2} / \mathrm{g}\right.$; Table 2, Fig. $5 \mathrm{a} ; \mathrm{N}_{2}$ sorption isotherms Supplementary Fig. S7). $S_{\mathrm{BET}}$ was correlated to activation time, but even the milk-derived activated carbons with the longest activation times had lower $S_{\mathrm{BET}}$ than most of the AC- $x x$-W- $t$. This difference did not reflect large discrepancies in the $S_{\mathrm{BET}}$ values of the carbonaceous portions of the activated carbons. Rather, when $S_{\mathrm{BET}}$ values were normalized to the combustible mass (fraction of mass lost upon heating to $800^{\circ} \mathrm{C}$ in air) of each $\mathrm{AC} \mathrm{(Fig.} 5 \mathrm{~b}$ ), there was no consistent difference between the activated carbons produced from HC- $x x$-W and HC- $x x-\mathrm{M}$, though activation time remained a significant determinant of $S_{\mathrm{BET}}$. Thus, in terms of $S_{\mathrm{BET}}$, the primary impact of using milk as a starting material was to contribute low-surface-area inorganic mass.

AC- $x x$-M- $t$ had different pore structures than AC- $x x$-W- $t$ (Supplementary Figs S7 and S8). All of the activated carbons contained micropores, as indicated by $\mathrm{N}_{2}$ uptake at low pressure, but some also contained mesopores, as revealed by hysteresis in $\mathrm{N}_{2}$ uptake from $\mathrm{P} / \mathrm{P}_{0} \sim 0.45$. Activated carbons generated from $\mathrm{HC}-x x-\mathrm{M}$, even using shorter activation times, were mesoporous, especially when no solid precursor was used in the hydrochar (i.e. for the AC-M- $t$ samples). This difference was likely due to the catalytic effect of the mineral components in $\mathrm{HC}-x x$-M in etching the carbon; a larger average pore size has been observed in polymer-derived activated carbons when $\mathrm{Ca}^{2+}$ was added prior to activation ${ }^{26}$. Micropore volume $\left(\mathrm{V}_{\mu \text {-pore }}\right)$ increased with activation time, and the AC- $x x-\mathrm{W}-t$ samples consistently had higher $\mathrm{V}_{\mu \text {-pore }}$ than the analogous AC- $x x-\mathrm{M}-t$ samples (Fig. $6 \mathrm{a}$ and Table 2). As was the case for the $S_{\mathrm{BET}}$, the difference in the $\mathrm{V}_{\mu \text {-pore }}$ between AC- $x x-\mathrm{W}-t$ and AC- $x x-\mathrm{M}-t$ disappeared upon normalizing to the combustible mass of the AC (Fig. 6b). 


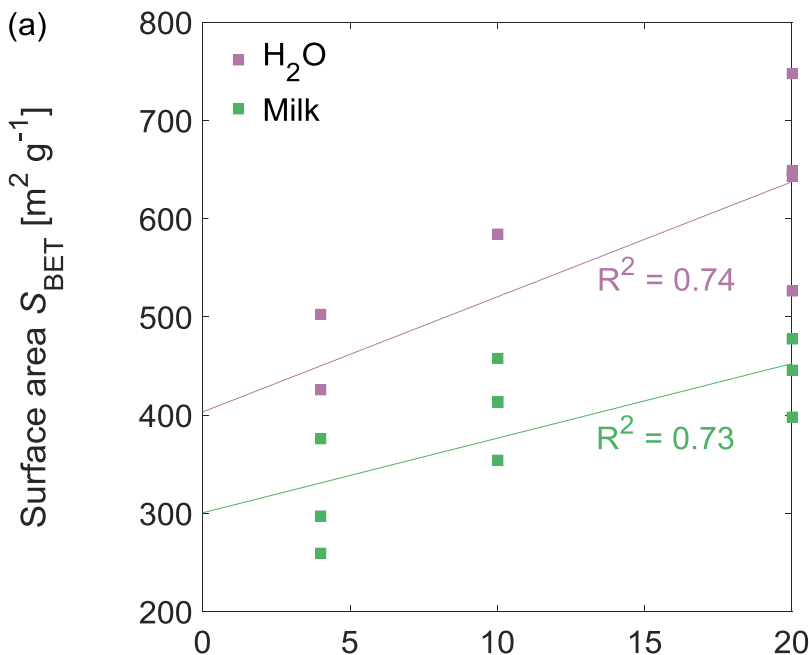

Activation time $[\mathrm{h}]$

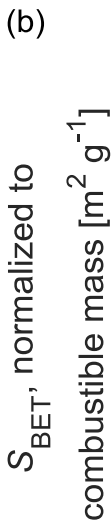

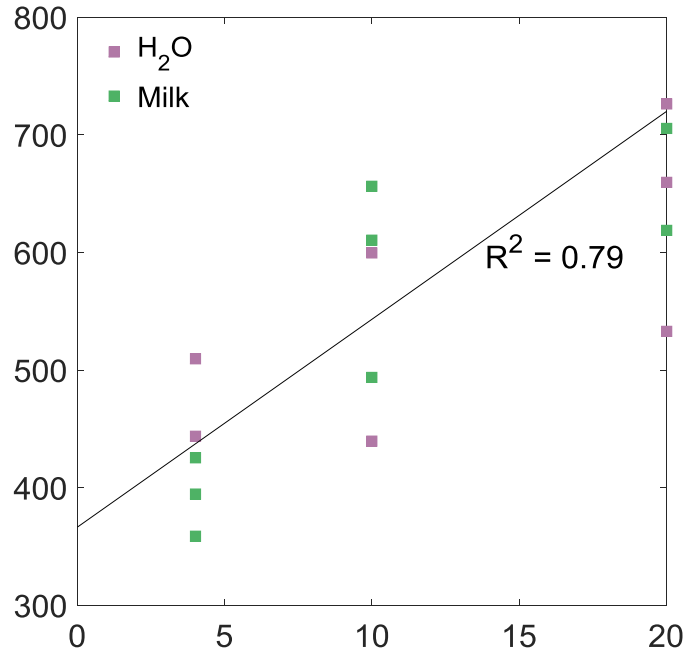

Activation time [h]

Figure 5. Brunauer-Emmett-Teller surface areas $S_{\mathrm{BET}}$ of the activated carbons derived from hydrochars produced in water or milk as functions of activation time. (a) Surface areas and (b) normalized surface areas. $S_{\text {BET }}$ calculated from the $\mathrm{N}_{2}$ adsorption isotherms (Supplementary Fig. S7) over $\mathrm{P} / \mathrm{P}_{0}=0.01-0.1$. Combustible mass is the mass fraction lost upon heating to $800^{\circ} \mathrm{C}$ in $25 \mathrm{~mL} \mathrm{~min}^{-1}$ of dry air.

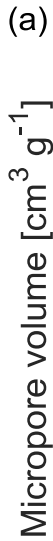
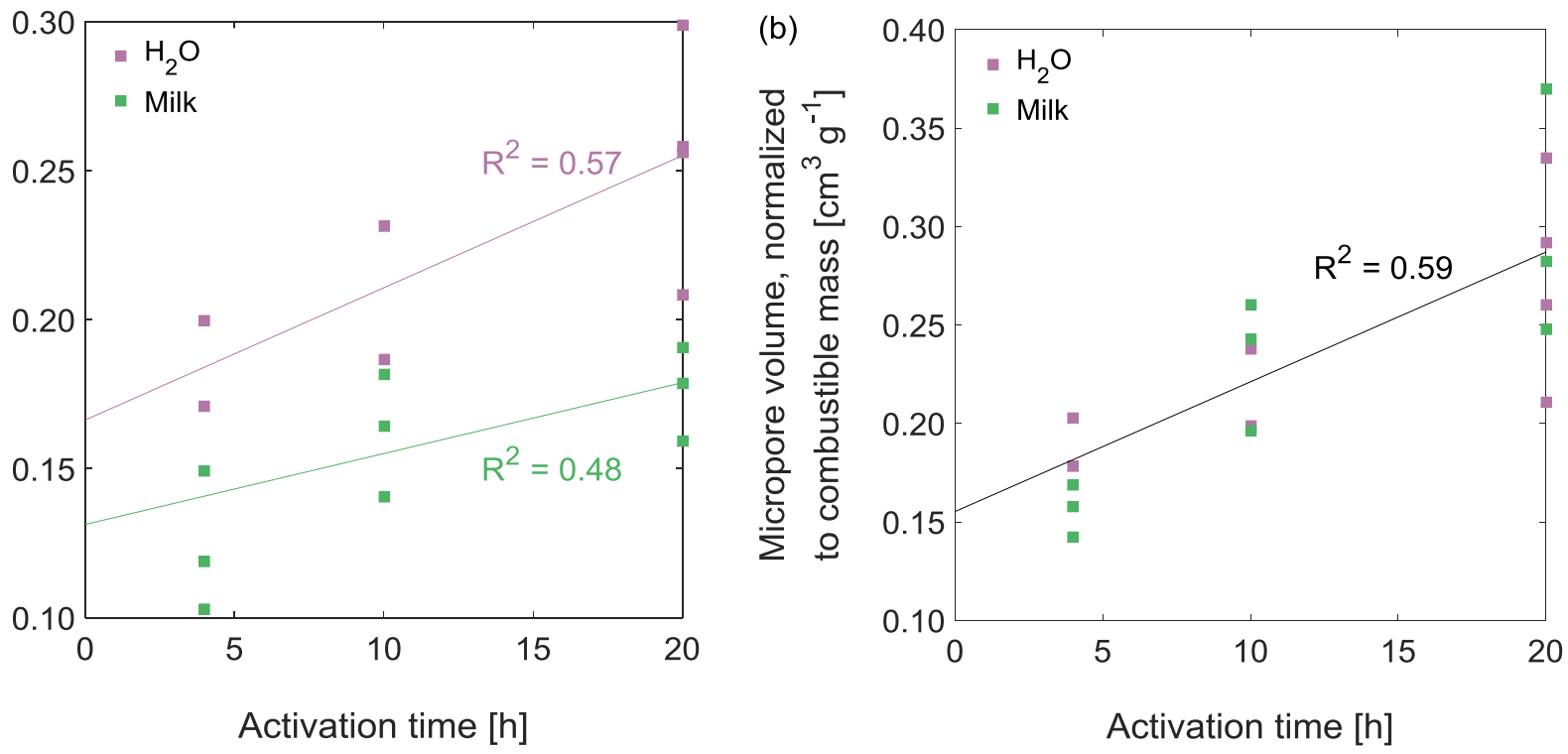

Figure 6. (a) Micropore volume $\mathrm{V}_{\mu \text {-pore }}$ and (b) normalized micropore volume $\mathrm{V}_{\mu \text {-pore }}$ for activated carbons (ACs) derived from hydrochars produced in water or milk as functions of activation time. Activation was under a flow of $\mathrm{CO}_{2}$ at $800^{\circ} \mathrm{C}$. Combustible mass is the fraction of mass lost when the $\mathrm{AC}$ is heated to $800^{\circ} \mathrm{C}$ in $25 \mathrm{~mL} \mathrm{~min}^{-1}$ air.

As $\mathrm{V}_{\mu \text {-pore }}$ is an excellent predictor of the $\mathrm{CO}_{2}$ sorption capacity of activated carbons, particularly under atmospheric $\mathrm{CO}_{2}$ pressure ${ }^{48}$, we expected the activated carbons generated from $\mathrm{HC}-x x$-M to take up less $\mathrm{CO}_{2}$ than those from HC- $x x$-W. Indeed, the AC- $x x-\mathrm{M}-t$ generally took up less $\mathrm{CO}_{2}$ than the corresponding AC- $x x-\mathrm{W}-t$ (Supplementary Figs S9-S13, Table 2), both at 15 and $101 \mathrm{kPa}$, and $\mathrm{CO}_{2}$ uptake was correlated to $\mathrm{V}_{\mu \text {-pore }}$, particularly at $101 \mathrm{kPa} \mathrm{CO}$ (Supplementary Fig. S14). Nevertheless, AC-CH-M-10 and AC-FF-M-10 each took up more than $1.6 \mathrm{mmol} \mathrm{g}^{-1} \mathrm{CO}_{2}$ at $15 \mathrm{kPa}$ and $0^{\circ} \mathrm{C}$, which is typical for activated carbons generated via activation in $\mathrm{CO}_{2}$ (Table 3). For example, it is in the range observed for activated carbons generated from the $\mathrm{CO}_{2}$-activation of other waste-derived hydrochars ${ }^{19}$, though lower than for activated carbons generated by $\mathrm{CO}_{2}$ - or steam-activation of isolated ${ }^{49}$ or chemically modified ${ }^{50}$ cellulose. 


\begin{tabular}{|c|c|c|c|c|}
\hline \multirow[b]{2}{*}{ Precursor } & \multicolumn{2}{|c|}{ Activation } & \multirow{2}{*}{$\begin{array}{l}\mathrm{CO}_{2} \text { uptake } \\
\left(0^{\circ} \mathrm{C}, 15 \mathrm{kPa}\right) \\
{\left[\mathrm{mmol} \mathrm{g}^{-1}\right]}\end{array}$} & \multirow[b]{2}{*}{ Ref. $^{a}$} \\
\hline & $T\left[{ }^{\circ} \mathrm{C}\right]$ & $t[\mathrm{~h}]$ & & \\
\hline Chitosan-crosslinked cellulose & 900 & 1 & 2.29 & 50 \\
\hline HC-FF-W & 800 & 10 & 1.8 & This work \\
\hline HC from RNA & 800 & 16 & 2.0 & 46 \\
\hline HC from grass cuttings & 800 & 2 & 1.8 & 19 \\
\hline Olive stones & 800 & 6 & 1.8 & 57 \\
\hline HC-FF-M & 800 & 10 & 1.6 & This work \\
\hline HC from biosludge & 800 & 2 & 1.0 & 19 \\
\hline
\end{tabular}

Table 3. $\mathrm{CO}_{2}$ uptake capacity of some activated carbons derived from the activation of biomass or biomassderived hydrochars (HCs) under $\mathrm{CO}_{2}$. ${ }^{\text {Reference. }}$

(a)

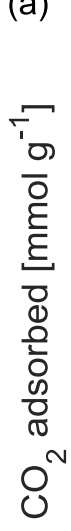

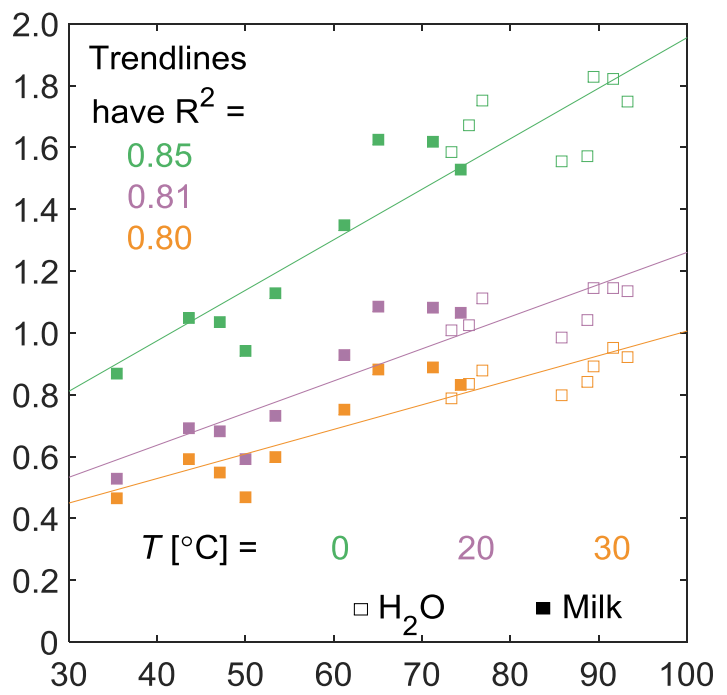

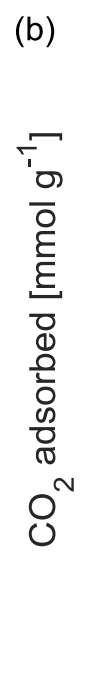

C content $[\%$ by mass]

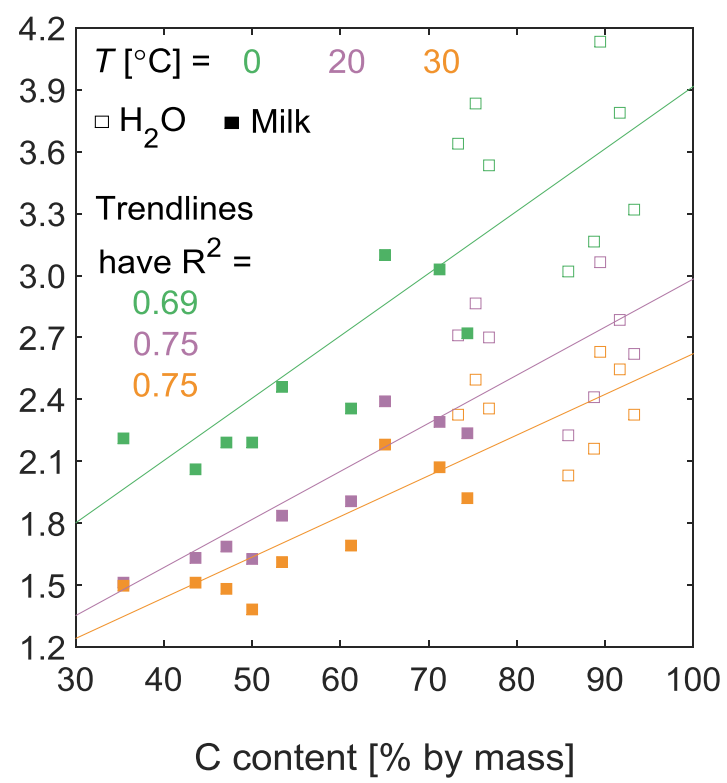

Figure 7. $\mathrm{CO}_{2}$ adsorption as a function of $\mathrm{C}$ content for activated carbons derived from hydrochars produced in water or milk. At $P_{\mathrm{CO} 2}=(\mathbf{a}) 15 \mathrm{kPa}$ and (b) $101 \mathrm{kPa}$.

Overall, the best predictor of $\mathrm{CO}_{2}$ uptake capacity in the activated carbons produced here, from hydrochars generated in water or in milk, was their carbon content (Fig. 7). The correlation between $\mathrm{C}$ content and $\mathrm{CO}_{2}$ uptake was particularly strong at $P_{\mathrm{CO} 2}=15 \mathrm{kPa}$ (Fig. 7a), the partial pressure of $\mathrm{CO}_{2}$ relevant to flue gas cleaning. Thus, despite that $\mathrm{V}_{\mu \text {-pore }}$ increased with activation time (Fig. 6), the relationship between activation time and $\mathrm{CO}_{2}$ uptake was more complex (Supplementary Fig. S15), especially for activated carbons derived from hydrochars generated in milk. The HC- $x x$-M lost more $\mathrm{C}$ atoms (and thus had greater concentrations of inorganics) upon extended 20-h activation (Table 2), so the highest $\mathrm{CO}_{2}$ uptakes on AC- $x x$-M- $t$ were obtained for activated carbons that had been activated for $10 \mathrm{~h}$. Consistent with the dependence of $\mathrm{CO}_{2}$ capacity on the carbon content of the activated carbon, the $\mathrm{CO}_{2}$ uptake on $\mathrm{AC}-x x-\mathrm{W}-t$ and $\mathrm{AC}-x x-\mathrm{M}-t$ were not systematically different after normalizing to combustible mass. These values were clearly influenced by activation time though; longer times gave higher $\mathrm{CO}_{2}$ uptake per unit combustible mass at $P_{\mathrm{CO} 2}=101 \mathrm{kPa}$, but the opposite was true for $\mathrm{CO}_{2}$ uptake at $P_{\mathrm{CO} 2}=15 \mathrm{kPa}$ (Supplementary Fig. S16). This difference can be understood in terms of pore development. $\mathrm{CO}_{2}$ uptake at low pressure depends on the volume of very small micropores $(\mathrm{d} \leq 0.5 \mathrm{~nm})$, whereas even larger micropores $(\mathrm{d} \leq 1 \mathrm{~nm})$ are important for $\mathrm{CO}_{2}$ uptake at $P_{\mathrm{CO} 2}=101 \mathrm{kPa}^{48}$. Activation in $\mathrm{CO}_{2}$ for extended times produces more volume in larger micropores and less in smaller micropores $^{51}$, and thus benefits $\mathrm{CO}_{2}$ uptake at $P_{\mathrm{CO} 2}=101 \mathrm{kPa}$.

The heats of adsorption $Q_{s t}$ for $\mathrm{CO}_{2}$ on the activated carbons produced from HC- $x x$-W and HC- $x x$-M (generally, $Q_{s t}=22-32 \mathrm{~kJ} \mathrm{~mol}^{-1}$; Supplementary Fig. S17) were consistent with the values for the physisorption of $\mathrm{CO}_{2}$ on similar activated carbons. They were in the range observed on activated carbons derived from polymers pyrolyzed in the presence of $\mathrm{KOH}^{52}$ as well as on polymer-derived activated carbons containing $\mathrm{CaO}$ nanoparticles $^{26}$, slightly higher than the values measured on a commercial NORIT activated carbons at similar loadings ${ }^{53}$, and slightly lower than those measured on an activated carbon obtained via the $\mathrm{CO}_{2}$-activation of a hydrochar formed from grass cuttings ${ }^{19}$.

Overall, the most important impact of using milk as the liquid phase in the hydrothermal carbonization to generate hydrochar-derived activated carbons for use as $\mathrm{CO}_{2}$ sorbents was to contribute inorganic mass that adsorbed little $\mathrm{CO}_{2}$. This inclusion of inorganic species had the net effect of producing activated carbons that took 
up less $\mathrm{CO}_{2}$ than analogous activated carbons made from hydrochars formed in water; however, the carbonaceous portions of the AC- $x x-\mathrm{M}-t$ and $\mathrm{AC}-x x-\mathrm{W}-t$ took up similar amounts of $\mathrm{CO}_{2}$ in adsorption processes that were energetically similar. In this way, the AC- $x x-\mathrm{M}-t$ behaved, at least in the context of $\mathrm{CO}_{2}$ sorption, like composites of activated carbons and inorganics. Thus although the use of waste milk to produce hydrochar-derived activated carbons was clearly feasible, and some of these activated carbons had $\mathrm{CO}_{2}$ uptake capacities in the same range as other activated carbons produced using $\mathrm{CO}_{2}$ as the activation agent $\left(1.6 \mathrm{mmolg}^{-1}\right.$ at $15 \mathrm{kPa}$ and $\left.0{ }^{\circ} \mathrm{C}\right)$, other uses of the AC- $x x-\mathrm{M}-t$ may be more interesting; future work will focus on applications that are favored by inorganic cations, such as calcium-catalyzed reactions.

\section{Data availability}

Figs 5 and 6 are constructed from data in Supplementary Figs S7 and S8, respectively, and Fig. 7 is constructed from data in Supplementary Figs S9-S13.

Received: 20 March 2019; Accepted: 25 September 2019;

Published online: 18 November 2019

\section{References}

1. Gustavsson, J., Cederberg, C., Sonesson, U., van Otterdijk, R. \& Meybeck, A. Global food losses and food waste-Extent, causes and prevention. FAO, Rome (2011).

2. Franke, U. et al. Kartläggning av matsvinnet i primärproduktionen. TemaNord 2013, 581 (2013).

3. Kushwaha, J. P., Srivastava, V. C. \& Mall, I. D. An Overview of Various Technologies for the Treatment of Dairy Wastewaters. Crit. Rev. Food Sci. Nutr. 51, 442-452 (2011).

4. Sze, K.-L., Yeung, W. S.-B. \& Fung, Y.-S. Separation and determination of metal cations in milk and dairy products by CE. Electrophoresis 28, 4156-4163 (2007).

5. Fang, J., Zhan, L., Ok, Y. S. \& Gao, B. Minireview of potential applications of hydrochar derived from hydrothermal carbonization of biomass. J. Ind. Eng. Chem. 57, 15-21 (2018).

6. Nizamuddin, S. et al. An overview of effect of process parameters on hydrothermal carbonization of biomass. Renewable Sustainable Energy Rev. 73, 1289-1299 (2017).

7. Kambo, H. S. \& Dutta, A. A comparative review of biochar and hydrochar in terms of production, physico-chemical properties and applications. Renewable Sustainable Energy Rev. 45, 359-378 (2015).

8. Krylova, A., Yu. \& Zaitchenko, V. M. Hydrothermal Carbonization of Biomass: A Review. Solid Fuel Chem. 52, 91-103 (2018).

9. Libra, J. A. et al. Hydrothermal carbonization of biomass residuals: a comparative review of the chemistry, processes and applications of wet and dry pyrolysis. Biofuels 2, 71-106 (2011).

10. Titirici, M.-M., Thomas, A. \& Antonietti, M. Back in the black: hydrothermal carbonization of plant material as an efficient chemical process to treat the $\mathrm{CO}_{2}$ problem? New J. Chem. 31, 787-789 (2007).

11. Malaták, J. \& Dlabaja, T. Hydrothermal carbonization of kitchen waste. Res. Agr. Eng. 62, 64-72 (2016).

12. Han, S. et al. Application of cow milk-derived carbon dots/Ag NPs composite as the antibacterial agent. Appl. Surf. Sci. 328, 368-373 (2015).

13. Zhu, X. et al. Role of Hydrochar Properties on the Porosity of Hydrochar-based Porous Carbon for Their Sustainable Application. ACS Sustainable Chem. Eng. 3, 833-840 (2015).

14. Rodríguez Correa, C. et al. Influence of the Carbonization Process on Activated Carbon Properties from Lignin and Lignin-Rich Biomasses. ACS Sustainable Chem. Eng. 5, 8222-8233 (2017).

15. Sevilla, M. \& Fuertes, A. B. Sustainable porous carbons with a superior performance for $\mathrm{CO}_{2}$ capture. Energy Environ. Sci. 4, 1765-1771 (2011).

16. Wei, L. \& Yushin, G. Nanostructured activated carbons from natural precursors for electrical double layer capacitors. Nano Energy 1, 552-565 (2012).

17. Jain, A., Balasubramanian, R. \& Srinivasan, M. P. Hydrothermal conversion of biomass waste to activated carbon with high porosity: A review. Chem. Eng. J. 283, 789-805 (2016).

18. Falco, C. et al. Tailoring the porosity of chemically activated hydrothermal carbons: Influence of the precursor and hydrothermal carbonization temperature. Carbon 62, 346-355 (2013).

19. Hao, W., Björkman, E., Lilliestråle, M. \& Hedin, N. Activated carbons prepared from hydrothermally carbonized waste biomass used as adsorbents for $\mathrm{CO}_{2}$. Appl. Energy 112, 526-532 (2013).

20. Coromina, H. M., Walsh, D. A. \& Mokaya, R. Biomass-derived activated carbon with simultaneously enhanced $\mathrm{CO}_{2}$ uptake for both pre and post combustion capture applications. J. Mater. Chem. A 4, 280-289 (2016).

21. Saetea, P. \& Tippayawong, N. In In Characterization of adsorbent from hydrothermally carbonized and steam activated sewage sludge; Newswood Ltd: Vol. 3, pp 1909-1912 (2013).

22. Falco, C., Sevilla, M., White, R. J., Rothe, R. \& Titirici, M.-M. Renewable Nitrogen-Doped Hydrothermal Carbons Derived from Microalgae. ChemSusChem 5, 1834-1840 (2012).

23. Creamer, A. E. \& Gao, B. Carbon-Based Adsorbents for Postcombustion $\mathrm{CO}_{2}$ Capture: A Critical Review. Environ. Sci. Technol. 50, 7276-7289 (2016).

24. Chen, Z. et al. Activated carbons and amine-modified materials for carbon dioxide capture-a review. Front. Environ. Sci. Eng. 7, 326-340 (2013).

25. D'Alessandro, D. M., Smit, B. \& Long, J. R. Carbon Dioxide Capture: Prospects for New Materials. Angew. Chem. Int. Ed. 49, 6058-6082 (2010).

26. Wu, Z. et al. One-pot generation of mesoporous carbon supported nanocrystalline calcium oxides capable of efficient $\mathrm{CO}_{2}$ capture over a wide range of temperatures. Phys. Chem. Chem. Phys. 13, 2495-2503 (2011).

27. Falco, C., Baccile, N. \& Titirici, M.-M. Morphological and structural differences between glucose, cellulose and lignocellulosic biomass derived hydrothermal carbons. Green Chem. 13, 3273-3281 (2011).

28. Dudley, R. L. et al. High-resolution carbon-13 CP/MAS NMR spectra of solid cellulose oligomers and the structure of cellulose II. J. Am. Chem. Soc. 105, 2469-2472 (1983).

29. Baccile, N. et al. Structural Characterization of Hydrothermal Carbon Spheres by Advanced Solid-State MAS ${ }^{13} \mathrm{C}$ NMR Investigations. J. Phys. Chem. C 113, 9644-9654 (2009).

30. Heilmann, S. M. et al. Hydrothermal carbonization of distiller's grains. Biomass Bioenergy 35, 2526-2533 (2011).

31. Heilmann, S. M. et al. Hydrothermal carbonization of microalgae II. Fatty acid, char, and algal nutrient products. Appl. Energy 88, 3286-3290 (2011).

32. Lu, Y., Levine, R. B. \& Savage, P. E. Fatty Acids for Nutraceuticals and Biofuels from Hydrothermal Carbonization of Microalgae. Ind. Eng. Chem. Res. 54, 4066-4071 (2015). 
33. Liese, H. C. Selected Terrestrial Minerals and Their Infrared Absorption Spectral Data (4000-300 $\left.\mathrm{cm}^{-1}\right)$. In: Infrared and Raman Spectroscopy of Lunar and Terrestrial Minerals; Karr, C., Ed.; Academic Press: pp 197-229 (1975).

34. Wang, J. \& Kaskel, S. KOH activation of carbon-based materials for energy storage. J. Mater. Chem. 22, 23710-23725 (2012).

35. Romero-Anaya, A. J., Ouzzine, M., Lillo-Ródenas, M. A. \& Linares-Solano, A. Spherical carbons: Synthesis, characterization and activation processes. Carbon 68, 296-307 (2014).

36. Wang, Q., Li, H., Chen, L. \& Huang, X. Monodispersed hard carbon spherules with uniform nanopores. Carbon 39, 2211-2214 (2001).

37. Titirici, M., Antonietti, M. \& Baccile, N. Hydrothermal carbon from biomass: a comparison of the local structure from poly- to monosaccharides and pentoses/hexoses. Green Chem. 10, 1204-1212 (2008).

38. Li, M., Li, W. \& Liu, S. Hydrothermal synthesis, characterization, and $\mathrm{KOH}$ activation of carbon spheres from glucose. Carbohydr. Res. 346, 999-1004 (2011)

39. Lee, K. K. et al. Tailored activated carbons for supercapacitors derived from hydrothermally carbonized sugars by chemical activation. RSC Adv. 6, 110629-110641 (2016).

40. Inagaki, M. Old but New Materials: "Carbons". In: New Carbons - Control of Structure and Functions; Inagaki, M., Ed.; Elsevier Science: Oxford, pp 1-29 (2000).

41. Degroot, W. F., Osterheld, T. H. \& Richards, G. N. The Influence of Natural and Added Catalysts in the Gasification of Wood Chars. In: Research in Thermochemical Biomass Conversion; Bridgwater, A. V., Kuester, J. L., Eds; Springer Netherlands: Dordrecht, pp 327-341 (1988).

42. Marsh, H. \& Rodríguez-Reinoso, F. Activation Processes (Chemical). In: Activated Carbon; Marsh, H., Rodríguez-Reinoso, F., Eds; Elsevier Science Ltd: Oxford, pp 322-365 (2006).

43. Lozano-Castelló, D., Marco-Lozar, J. P., Falco, C., Titirici, M.-M. \& Cazorla-Amorós, D. Porous Biomass-Derived Carbons: Activated Carbons. In: Sustainable Carbon Materials from Hydrothermal Processes; Titirici, M. -., Ed.; John Wiley \& Sons, Ltd: West Sussex, UK, pp 75-100 (2013).

44. Mestre, A. S., Freire, C., Pires, J., Carvalho, A. P. \& Pinto, M. L. High performance microspherical activated carbons for methane storage and landfill gas or biogas upgrade. J. Mater. Chem. A 2, 15337-15344 (2014).

45. Sevilla, M. \& Fuertes, A. B. A Green Approach to High-Performance Supercapacitor Electrodes: The Chemical Activation of Hydrochar with Potassium Bicarbonate. ChemSusChem 9, 1880-1888 (2016).

46. Lee, K. K., Church, T. L. \& Hedin, N. RNA as a Precursor to N-Doped Activated Carbon. ACS Appl. Energy Mater. 1, 3815-3825 (2018).

47. Sevilla, M., Ferrero, G. A. \& Fuertes, A. B. Beyond KOH activation for the synthesis of superactivated carbons from hydrochar. Carbon 114, 50-58 (2017)

48. Presser, V., McDonough, J., Yeon, S.-H. \& Gogotsi, Y. Effect of pore size on carbon dioxide sorption by carbide derived carbon. Energy Environ. Sci. 4, 3059-3066 (2011).

49. Heo, Y.-J. \& Park, S.-J. A role of steam activation on $\mathrm{CO}_{2}$ capture and separation of narrow microporous carbons produced from cellulose fibers. Energy $91,142-150$ (2015).

50. Xu, C., Ruan, C.-Q., Li, Y., Lindh, J. \& Strømme, M. High-Performance Activated Carbons Synthesized from Nanocellulose for $\mathrm{CO}_{2}$ Capture and Extremely Selective Removal of Volatile Organic Compounds. Adv. Sustainable Syst. 2, 1700147 (2018).

51. Hao, W., Björkman, E., Yun, Y., Lilliestråle, M. \& Hedin, N. Iron Oxide Nanoparticles Embedded in Activated Carbons Prepared from Hydrothermally Treated Waste Biomass. ChemSusChem 7, 875-882 (2014).

52. Choma, J., Stachurska, K., Marszewski, M. \& Jaroniec, M. Equilibrium isotherms and isosteric heat for $\mathrm{CO}_{2}$ adsorption on nanoporous carbons from polymers. Adsorption 22, 581-588 (2016).

53. Himeno, S., Komatsu, T. \& Fujita, S. High-Pressure Adsorption Equilibria of Methane and Carbon Dioxide on Several Activated Carbons. J. Chem. Eng. Data 50, 369-376 (2005).

54. Brunauer, S., Emmett, P. H. \& Teller, E. Adsorption of Gases in Multimolecular Layers. J. Am. Chem. Soc. 60, 309-319 (1938).

55. Dubinin, M. M. Fundamentals of the theory of adsorption in micropores of carbon adsorbents: Characteristics of their adsorption properties and microporous structures. Carbon 27, 457-467 (1989).

56. Dubinin, M. M., Zaverina, E. D. \& Radushkevich, L. V. Sorption and structure of active carbons. I. Adsorption of organic vapors. Zh. Fiz. Khim. 21, 1351-62. (1947).

57. González, A. S., Plaza, M. G., Rubiera, F. \& Pevida, C. Sustainable biomass-based carbon adsorbents for post-combustion $\mathrm{CO}_{2}$ capture. Chem. Eng. J. 230, 456-465 (2013).

\section{Acknowledgements}

We thank Marie Ernstsson, RISE Bioscience and Materials, for performing X-ray photoelectron spectroscopy, as well as MEDAC UK for elemental analyses. NH and TLC are grateful for support from the Swedish Research Council (VR, grant number 2016-03568). NH thanks the Swedish Foundation for Strategic Environmental Research (Mistra; project Mistra TerraClean, project number 2015/31) and the European Union's Horizon 2020 research and innovation programme under the Marie Skłodowska-Curie grant agreement No 721991, for financial support. KKL was supported by a grant from the Carl Trygger foundation, and SHY thanks the University of Gabes (Tunisia) and Prof. Mohamed Bagane for support. Open access funding provided by Stockholm University.

\section{Author contributions}

N.H. and T.L.C. conceived and designed the study. S.H.Y., K.K., N.H. and T.L.C. performed the experiments and measurements. BA contributed to the interpretation of the IR spectra and powder X-ray diffraction patterns. T.L.C. wrote the manuscript with contributions from S.H.Y. and N.H. All authors reviewed the manuscript.

\section{Competing interests}

The authors declare no competing interests.

\section{Additional information}

Supplementary information is available for this paper at https://doi.org/10.1038/s41598-019-53361-5.

Correspondence and requests for materials should be addressed to T.L.C.

Reprints and permissions information is available at www.nature.com/reprints.

Publisher's note Springer Nature remains neutral with regard to jurisdictional claims in published maps and institutional affiliations. 
(c) (i) Open Access This article is licensed under a Creative Commons Attribution 4.0 International License, which permits use, sharing, adaptation, distribution and reproduction in any medium or format, as long as you give appropriate credit to the original author(s) and the source, provide a link to the Creative Commons license, and indicate if changes were made. The images or other third party material in this article are included in the article's Creative Commons license, unless indicated otherwise in a credit line to the material. If material is not included in the article's Creative Commons license and your intended use is not permitted by statutory regulation or exceeds the permitted use, you will need to obtain permission directly from the copyright holder. To view a copy of this license, visit http://creativecommons.org/licenses/by/4.0/.

(C) The Author(s) 2019 